УДК: 004.05

Юрій Васильович Кравченко (доктор технічних наук, професор)

Андрій Петрович Мусієнко (доктор технічних наук)

Максим Георгійович Тищенко (кандидат технічних наук)

Спартак Юрійович Гогонянц (кандидат військових наук, с.н.с.)

Національний університет оборони Украӥни імені Івана Черняховського, Київ, Украӥна

\title{
МЕТОДИКА ОПРАЦЮВАННЯ ЕКСПЕРТНИХ ДАНИХ ДЛЯ УДОСКОНАЛЕННЯ СИСТЕМИ ДИСТАНЦІЙНОГО НАВЧАННЯ В ЗБРОЙНИХ СИЛАХ УКРАЇНИ
}

В роботі було проведено класифікацію засобів автоматизації освітнього процесу у системі військової освіти. На основі проведеного аналізу було визначено, щзо одним із важливих факторів ефективного функиіонування системи дистанційного навчання є наявність експертів, які контролюють якість дистанційних курсів та пропонують методи їх удосконалення. 3 метою розроблення механізму роботи експертів щчодо оцінювання ефективності та якості курсів дистанційного навчання була запропонована методика здійснення колективної експертизи ефективності та якості курсів дистанційного навчання та опрацювання отриманих експертних даних у групі експертів. Алгоритм розрахунків з використанням запропонованої методики передбачає визначення фахового рівня експертів; оброблення значень показників, визначених експертами; визначення узагальненого значення певного показника; визначення значення узагальненого показника.

Ключові слова: дистанційне навчання; експертна оцінка; інформаційні технології; військова ocвima.

\section{Вступ}

Швидкий розвиток комп'ютерних технологій став поштовхом до розвитку інформаційного суспільства. Об'єктивним процесом постіндустріального інформаційного суспільства є інформатизація та інтелектуалізація освіти. Вона полягає в глобальній інформатизації інтелектуальної діяльності за рахунок використання інформаційних технологій та можливості підбору відповідних курсів навчання в залежності від рівня підготовленості слухача. Інформаційні технології за своїми дидактичними властивостями впливають на всі компоненти навчання. Завдяки процесу інформатизації стала можливою нова синтетична, інтегральна гуманістична форма навчання - дистанційне навчання, яке вбирає в себе кращі риси традиційних форм навчання i добре 3 ними інтегрується [1]. Згідно із Законом України „Про вищу освіту" дистанційна освіта набула офіційного статусу самостійної форми навчання i розвивається швидкими темпами.

Обгрунтуємо доцільність створення системи дистанційного навчання у Збройних Силах України. В Україні та за кордоном вже накопичений значний досвід впровадження дистанційного навчання. Увага до цієї форми навчання спостерігається як у цивільній, так і у військовій освіті [2]. В умовах їх інтеграції стає очевидним, що науково-дослідна та практична робота у військових навчальних закладах над проблемами дистанційного навчання повинна бути постійною i безперервною. Водночас слід зауважити, що специфіка підготовки військових фахівців визначає деякі особливості впровадження дистанційної форми навчання. Освітній процес за дистанційною формою навчання на першому етапі втілення можна поділити на чотири напрями $[3,4]$ : навчання в межах системи військової освіти слухачів, курсантів, студентів ВВНЗ (ВНП ЗВО) (підготовка офіцерів запасу), фахівців для інших силових структур та іноземних військовослужбовців;

підвищення кваліфікації та курсова підготовка, індивідуальна підготовка офіцерів Збройних Сил України;

надання можливості військовослужбовцям строкової служби (служби за контрактом) отримати освіту за дистанційною формою навчання за рахунок МО України (умови контракту); 
надання можливості військовослужбовцям Збройних Сил України отримати вищу освіту за дистанційною формою навчання за рахунок фізичних або юридичних осіб.

Отже, дистанційна форма навчання у системі військової освіти призвана вирішувати специфічні завдання, які важко вирішити 3 використанням традиційних форм, що потребують впровадження нових педагогічних технологій навчання; застосування засобів телекомунікаційного зв'язку; розвитку творчої складової освіти; створення віртуального інформаційно-освітньог середовища.

Постановка проблеми. Для реалізації освітнього процесу у системі військової освіти за дистанційної формою навчання необхідне створення системи дистанційного навчання військової освіти та розроблення механізму роботи експертів щодо оцінювання ефективності та якості курсів дистанційного навчання. Це завдання передбачає: створення нової нормативно-правової бази; визначення джерел фінансування; створення організаційних структур, які забезпечать реалізацію цієї форми навчання; використання висококваліфікованих експертів для аналізу та удосконалення розроблених курсів дистанційного навчання.

Таким чином актуальною $\epsilon$ проблема розроблення теоретичних підходів до здійснення колективної експертизи ефективності та якості курсів дистанційного навчання та опрацювання отриманих експертних даних в групі експертів.

Метою статті $\epsilon$ формулювання методики роботи експертів щодо оцінювання ефективності та якості курсів дистанційного навчання.

\section{Виклад основного матеріалу дослідження}

Використання інформаційних технологій у системі військової освіти в першу чергу спрямовано на розвиток інформаційного забезпечення навчального процесу шляхом застосування інформаційних систем для денного (заочного) та дистанційного навчання, електронних підручників, автоматизованих систем контролю знань, автоматизованих систем проектування та наукових досліджень, автоматизованих систем моделювання, баз даних та баз знань. Також широкого застосування набули автоматизовані бібліотечні системи, довідникові системи тощо. Всі ці системи дозволяють сформувати та підтримувати роботу єдиного інформаційного простору [5]. Окрім цього, існує другий тип автоматизованих систем управління у системі військової освіти, які призначені для підтримки функціонування системи дистанційної освіти 3 точки зору адміністративноуправлінського функціоналу. Це автоматична система управління для планування, аналітичної обробки, супроводу та управління адміністративно-господарської та фінансовоекономічної діяльності. Таким чином, можна класифікувати автоматизовані системи за двома напрямами: автоматизовані системи управління навчальним процесом військовослужбовців та автоматизовані системи управління для забезпечення даного навчання.

Отже, автоматизовані системи управління класифікуються за характером задач, які вони здатні вирішувати. Це автоматизовані системи адміністративного управління, управління персоналом, управління документами, управління науково-дослідними роботами, організаційного та матеріально-технічного управління, управління якістю освіти, управління документообігом.

Як зазначено в [6], інформаційні технології відкривають нові умови та можливості для сфери освітньої діяльності: покращення навчального процесу, оновлення навчальних програм, оперативного пошуку інформації тощо. В [7] розглядається створення корпоративної інформаційної системи вищого навчального закладу, яка враховує галузеву специфіку діяльності. Розширення та поява нових видів діяльності вимагає розвитку організаційної структури, яка визначає функції та склад управління структурними підрозділами. При цьому змін зазнають також і структурні одиниці.

Особливостями створення інформаційних систем дистанційного навчання військовослужбовців є [8]:

діяльність в різних областях,

багатопрофільність;

різноманіття форм організації навчальної роботи, методів;

просторово розгалужена інфраструктура.

При створенні інтегрованої інформаційної системи дистанційного навчання військовослужбовців необхідно:

дотримуватись модульності структури; забезпечувати єдині вимогу до інтерфейсів; використовувати надійні, здатні до розширення, програмні та апаратні рішення;

залучати спеціалістів 3 предметних областей тих задач, які автоматизуються - управлінська сфера, навчання, наука тощо.

Створена таким чином інформаційна система буде здатна вирішувати поставлені задачі та сприятиме покращенню діяльності системи дистанційного навчання Збройних Сил України. Проте, жодна система дистанційного навчання не може існувати без експертів, які контролюють якість дистанційних курсів та пропонують методи їх удосконалення. В першу, основними експертами 3 оцінювання якості дистанційних курсів $\epsilon$ 158 ISSN2311-7249(Print)/ISSN2410-7336(Onfine) Сучасні інббормаційні технології у сбері безпеки та оборони № 1 (37)/2020 
безпосередньо ті, хто навчається. Саме вони можуть надати найбільш об'єктивну інформацію щодо зручності інтерфейсу курсу, логічності структурування та подання навчальної інформації, та рекомендацій щодо покращення, як змістовної частини, так i формату курсу. Але, на етапі розроблення та удосконалення дистанційних курсів необхідно мати групу висококваліфікованих експертів предметної галузі та тих, хто має досвід розроблення навчальних матеріалів із використанням технологій дистанційного навчання.

Методи оброблення експертної інформації можна розподілити на три основні групи: статистичні, алгебраїчні та шкалування. Статистичні методи основані на ідеї, що відхилення оцінок експертів від істинних здійснюється у силу випадкових причин; завдання полягає у тому, щоб відновити це істинне значення 3 найменшою похибкою. Зміст алгебраїчних методів полягає в тому, що на множині допустимих оцінок задається відстань. Результат визначається як оцінка, сума відстаней від якої до оцінок експертів буде мінімальна. Метод шкалування полягає у тому, що завдяки експертній інформації про ступінь розбіжностей об’єктів встановлюється мінімальний або близький до мінімального набір критеріїв. Далі на основі даних критеріїв проводиться оцінювання об'єктів та виявляються розбіжності. В роботі [9] запропоновано використання спектрального підходу до оцінювання експертних знань, але на практиці цей підхід поки що не використовується. Авторами [10-14] дослідженні питання розвитку систем дистанційного навчання, які є теоретичною основою запропонованою в статті методики.

В роботі пропонується методика опрацювання експертних даних в групі експертів. Вимоги до методики: урахування професійного рівня експертів; нейтралізація максимально можливою мірою фактору суб'єктивізму.

Загальний зміст методики:

здійснюється визначення фахового рівня експертів;

визначається експерт-лідер на основі оцінки фахового рівня експертів;

усі значення показників, визначені експертами, перераховуються 3 урахуванням їх професійного рівня відносно експерта-лідера;

загальна оцінка за кожним показником визначається як середньоарифметична величина оцінок усіх експертів.

Алгоритм розрахунків.

1. Визначення фахового рівня експертів.

3 метою об'єктивізації та узагальнення оцінок експертів застосований підхід, який полягає у максимальному урахуванні рівня професійності під час узагальнення даних, отриманих від експертів. Для цього були визначені показники оцінки фахового рівня експертів $\mathrm{f}_{\mathrm{e}}$.

Для спрощення процедури урахування досвіду експертів показники оцінюються за двозначною шкалою:

1 - наявність визначених умов;

0 - відсутність визначених умов.

Введемо значення інтегрального показника як сума значень всіх показників.

3 метою виділення одного лідера серед фахівців, які мають найвищий фаховий рівень, як правило, надають перевагу тому, хто має теоретичний та практичний досвід роботи у сфері розроблення курсів дистанційного навчання.

2. Перерахування значень показників, визначених експертами. Різниця між фаховим рівнем експерта-лідера і експерта визначається за формулою

$$
\Delta \mathrm{f}_{\mathrm{e}}=\mathrm{f}_{\mathrm{el}}-\mathrm{f}_{\mathrm{e}}
$$

де: $\mathrm{f}_{\mathrm{e}}\left(\mathrm{f}_{\mathrm{el}}\right)$ - фаховий рівень експерта (експерталідера), який показує ступінь відповідності визначених ним показників реальному стану справ (значення належать інтервалу [0...1]).

Величина розбіжності між значеннями певного показника, визначеними експертом-лідером i експертом, визначається за формулою

$$
\Delta \mathrm{q}_{\mathrm{e}}=\mathrm{q}_{\mathrm{el}}-\mathrm{q}_{\mathrm{e}}
$$

де: $\mathrm{q}_{\mathrm{e}}\left(\mathrm{q}_{\mathrm{el}}\right)_{-}$значення певного показника, визначене експертом (експертом-лідером).

Перераховане значення показника, визначене експертом, 3 урахуванням поправки на його фаховий рівень, визначається за формулою

$$
\mathrm{q}_{\mathrm{e}}^{\prime}=\mathrm{q}_{\mathrm{e}}+\Delta \mathrm{f}_{\mathrm{e}} \cdot \Delta \mathrm{q}_{\mathrm{e}}=\mathrm{q}_{\mathrm{e}}+\left(\mathrm{f}_{\mathrm{el}}-\mathrm{f}_{\mathrm{e}}\right) \cdot\left(\mathrm{q}_{\mathrm{el}}-\mathrm{q}_{\mathrm{e}}\right)
$$

Фізичний зміст другої складової у цій формулі полягає у тому, що вона визначає ту частку похибки, яка вноситься експертом за рахунокрізниці у фаховому рівні між ним та експертомлідером $\quad\left(\mathrm{f}_{\mathrm{el}}-\mathrm{f}_{\mathrm{e}}\right)$. З Знак цієї складової визначається різницею $\left(\mathrm{q}_{\mathrm{el}}-\mathrm{q}_{\mathrm{e}}\right)$, адже різниця $\left(\mathrm{f}_{\mathrm{el}}-\mathrm{f}_{\mathrm{e}}\right)$ завжди має знак «+», оскільки значення фахового рівня експерта-лідера не може бути нижчим за фаховий рівень інших експертів. Отже, перераховане значення певного показника $\mathrm{q}_{\mathrm{e}}^{\prime}$, визначене експертом, буде завжди ближчим до значення цього ж показника, визначеного експертом-лідером $\mathrm{q}_{\mathrm{el}}$.

3. Визначення узагальненого значення певного показника. 
Отримані на першому кроці перераховані значення певного показника, як i початково визначені експертами з різним фаховим рівнем, відображають їх оцінки значення цього показника так, якби кожний 3 експертів мав такий же фаховий рівень, який у експерта-лідера. Це припущення дає підстави для того, щоб узагальнене значення певного показника визначати як середньоарифметичне від значень показника, визначених кожним експертом

$$
\mathrm{q}_{\mathrm{yj}}=\frac{\sum_{\mathrm{i}=1}^{\mathrm{N}} \mathrm{q}_{\mathrm{ei}}^{\prime j}}{\mathrm{~N}},
$$

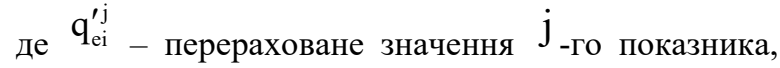
початкове визначене $\mathrm{i}_{\text {-м }}(\mathrm{i} \in[1, \ldots, \mathrm{N}])$;

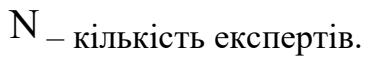

4. Визначення значення узагальненого показника.

Для визначення узагальненого показника стану ситуації за даною методикою необхідно визначити перераховані значення важливості ј-го показника. Величина розбіжності між значеннями важливості певного показника, визначеними експертомлідером і експертом, визначається за формулою

$$
\Delta \mathrm{w}_{\mathrm{e}}=\mathrm{w}_{\mathrm{el}}-\mathrm{w}_{\mathrm{e}},
$$

де $\mathrm{w}_{\mathrm{e}}\left(\mathrm{w}_{\mathrm{el}}\right)$ - значення важливості певного показника, визначене експертом (експертомлідером).

Перераховане значення важливості показника, визначене експертом, з урахуванням поправки на його фаховий рівень, визначається за формулою $\mathrm{w}_{\mathrm{e}}^{\prime}=\mathrm{w}_{\mathrm{e}}+\Delta \mathrm{f}_{\mathrm{e}} \cdot \Delta \mathrm{w}_{\mathrm{e}}=\mathrm{w}_{\mathrm{e}}+\left(\mathrm{f}_{\mathrm{el}}-\mathrm{f}_{\mathrm{e}}\right) \cdot\left(\mathrm{w}_{\mathrm{el}}-\mathrm{w}_{\mathrm{e}}\right)$. Фізичний зміст другої складової у цій формулі аналогічний розглянутому раніше. Узагальнене значення важливості певного показника визначається також як середньоарифметичне від перерахованих значень важливості показника:

$$
\mathrm{w}_{\mathrm{yj}}=\frac{\sum_{\mathrm{i}=1}^{\mathrm{N}} \mathrm{w}_{\mathrm{ei}}^{\prime \mathrm{j}}}{\mathrm{N}} .
$$

Наступним кроком визначається нормоване значення важливості у-го показника за формулою

$$
\mathrm{W}_{\mathrm{Hj}}=\frac{\mathrm{W}_{\mathrm{yj}}}{\sum_{\mathrm{i}=1}^{\mathrm{N}} \mathrm{W}_{\mathrm{ei}}^{\prime \mathrm{j}}},
$$

де $\mathrm{W}_{\mathrm{yj}}$ - значення важливості j-го показника

$$
(\mathrm{j} \in[1, \ldots, \mathrm{K}]) \text {; }
$$

$\mathrm{K}$ - кількість показників.

Значення узагальненого показника ефективності визначається за формулою

$$
\mathrm{q}_{\mathrm{y}}=\sum_{\mathrm{j}=1}^{\mathrm{K}} \mathrm{q}_{\mathrm{yj}} \mathrm{w}_{\mathrm{Hj}}
$$

Результати аналізу надаються кожною комісією у вигляді розгорнутого висновку, в якому визначається обгрунтована пропозиція комісії щодо ефективності та якості певного курсу дистанційного навчання.

Завданням експертизи у цілому є отримання об'єктивних характеристик (як позитивних, так i негативних) та складання пропозицій щодо ефективності розроблених курсів в системі дистанційного навчання Збройних Сил України. Після обговорення кожного з вузлових питань в експертній комісії готується висновок, що $\epsilon$ першою ітерацією пропозицій щодо вирішення питання ефективності розробленого курсу (ï кількість дорівнюе кількості комісій) та передається для обговорення в підрозділ дистанційного навчання ВВНЗ (ВНП ЗВО). Комісія обговорює зауваження, вносить корективи. Таким чином відбувається удосконалення системи дистанційного навчання Збройних Сил України.

\section{Висновки і перспективи подальших досліджень}

В роботі визначено, що методи експертного аналізу $\epsilon$ основними в категорії методів інтелектуального аналізу даних. Когнітивні функції експерта часто неможливо описати аналітичними чи іншими способами. Тому пропонується використовувати саме їх для аналізу проблем, отримання експертної інформації в механізмі прийняття рішень щодо ефективності курсів дистанційного навчання та розроблення рекомендацій $з$ покращення існуючих курсів. В роботі запропонована методика здійснення колективної експертизи та опрацювання експертних даних в групі експертів. Дана методика використовується 3 урахування професійного рівня експертів, нейтралізації максимально можливою мірою фактору суб'єктивізму, максимальної простоти та орієнтації на використання фахівців, які мають справу 3 роботою та навчанням в галузі військових наук та інформаційних технологій.

\section{Лimepamypa}

1. Jacob W. Interdisciplinary trends in higher education / Наказ Міністерства Оборони України від 21.12.2015 Palgrave Communications. 2015. Vol. 1. №744 Про затвердження Концепції дистанційного URL:https://www.nature.com/articles/palcomms20151. 2. навчання у Збройних Силах України. - [Електр. ресурс]. 160 ISSN2311-7249(Print)/ISSN2410-7336(Onine) Сучасні інббормахійні технологї̈у сббері безпеки та оборони $\mathcal{N o} 1$ (37)/2020 
- Режим доступу: www.mil.gov.ua/science and defense. 3. Walcutt, J.J. \& Schatz, S. (Eds.) (2019). Modernizing Learning: Building the Future Learning Ecosystem. Washington, DC: Government Publishing Office. License: Creative Commons Attribution CC BY 4.0 IGO 4. Voloshinov S. Modern trends for higher education in Ukraine/Engineering and Educational Technologies, 2018, 6 (4), pp. 38-46. DOI https://doi.org/10.30929/23079770.2018.06.04.04 5. Доктрина інформаційної безпеки України, затверджена Указом Президента України від 8 липня 2009 року № 514/2009 [Електронний ресурс].Режим доступу : Офіційне Інтернет-представництво Президента України http://www.president.gov.ua 6. М. Moore, (Ed.). Handbook of distance education. Edition 3, Routledge, 2013. 7. Гніденко М.П. Новий підхід до педагогічного процесу в умовах інформатизації / М.П. Гніденко, О.О. Ільїн, О.В. Кліменко // Вісник Державного університету інформаційно-комунікаційних технологій. - К.:ДУІКТ, 2012. - Т.10, №3. - С. 61-68. 8. Опар Н.В. Особливості нормативно-правового забезпечення якості вищої освіти в Україні в умовах євроінтеграції. Теорія та практика державного управління i місцевого самоврядування. Електронне наукове фахове видання. - 2015. - №1. [Електронний pecypc]. - Режим доступу: http://elzbirndu.at.ua/index/zmist_2015_1/0-18

9. Організація та використання технологій дистанційного навчання у Збройних Силах України : навч.-метод. посіб. / колектив авторів ; за заг. ред. С. М. Салкуцана. - К. : НУОУ, 2017. - 124 с. 10. Салкуцан С.М. Стан системи дистанційного навчання Збройних Сил України та погляди на іiі подальший розвиток / C.M. Салкуцан, М. Г. Тищенко, С.Ю. Гогонянц // Матеріали II Міжнародної науковопрактичної конференції "Проблеми впровадження дистанційного навчання в освітньому процесі вищих військових навчальних закладів та можливі шляхи їх вирішення". - К.: НУОУ. - 2019. - С. 170-173. 11. Обгрунтування рекомендацій щодо удосконалення системи дистанційного навчання Збройних Сил України: звіт про НДР (остат.) / НУОУ; кер. С.М.Салкуцан; викон.: С. Ю. Гогонянц [та ін.]. шифр “Адель”. №0018u005049.,К. : НУОУ. - 2019. - 185 с. 12. Дистанційний навчальний процес : навчальний посібник [за ред. В. Ю. Бикова та В. М. Кухаренка.]. - К. : Міленіум, 2005. - 292 с. 13. Лснков С.В., Гахович С.В., Гунченко Ю.О., Лукін В.С., Шворов С.А. Побудова та використання систем дистанційного навчання 3 елементами штучного інтелекту: Монографія. - Одеса, Вид-во ВМВ, 2014. - 324 с. 14. Об'єктно-орієнтоване програмування: лабораторний практикум. Уклад.: О.В. Коба, С.В. Пустова. - К.: НАУ, 2011. $-76 \mathrm{c}$.

\title{
МЕТОДИКА ОБРАБОТКИ ЭКСПЕРТНЫХ ДАННЫХ ДЛЯ УСОВЕРШЕНСТВОВАНИЯ СИСТЕМЫ ДИСТАНЦИОННОГО ОБУЧЕНИЯ В ВООРУЖЕННЫХ СИЛАХ УКРАИНЫ
}

\author{
Юрий Васильевич Кравченко (доктор технических наук, профессор) \\ Андрей Петрович Мусиенко (доктор технических наук) \\ Максим Георгиевич Тищенко (кандидт технических наук) \\ Спартак Юрьевич Гогонянц (кандидат военных наук, с.н.с.)
}

\section{Национальный университет обороны Украины имени Ивана Черняховского, Киев, Украина}

В работе было проведено классификацию средств автоматизации образовательного процесса в системе военного образования. На основе проведенного анализа было определено, что одним из важных факторов эффективного функиионирования системы дистанционного обучения является наличие экспертов, которые контролируют качество дистанционных курсов и предлагают методы их совершенствования. С иелью разработки механизма работы экспертов по оцениванию эффективности и качества курсов дистаниионного обучения была предложена методика осуществления коллективной экспертизы эффективности и качества курсов дистанционного обучения и обработки полученных экспертных данных в группе экспертов. Алгоритм расчетов с использованием предложенной методики предполагает определение профессионального уровня экспертов; обработки значений показателей, определенных экспертами; определение обобщенного значения определенного показателя; определение значения обобщенного показателя.

Ключевые слова: дистанционное обучение; экспертная оценка; информационные технологии; военное образование.

\section{THE EXPERT DATA PROCESSING METHOD FOR THE DISTANCE LEARNING SYSTEM IMPROVEMENT IN THE ARMED FORCES OF UKRAINE}

Yurii Kravchenko (Doctor of Technical Sciences, Professor)

Andrii Musienko (Doctor of Technical Sciences)

Maksym Tyshchenko (Candidate of Technical Sciences)

Spatak Hohoniants (Candidate of Military Sciences, Senior Research Fellow) 


\section{The National Defence University of Ukraine named after Ivan Cherniakhovskyi, Kyiv, Ukraine}

The classification of educational process automation tools in the military education system was carried out in the paper. Based on the analysis, it was determined that one of the important factors in the effective functioning of the distance learning system is the availability of experts who monitor the quality of distance learning courses and offer methods for improving them. The method for conducting the collective examination of the effectiveness and quality of distance learning courses and processing the received expert data in an expert group was proposed in order to develop the mechanism for experts to assess the effectiveness and quality of distance learning courses. The calculation algorithm of the proposed method involves determining the professional level of experts; processing the values of indicators determined by experts; determination of the generalized value of a particular indicator; determination of the value of a generalized indicator.

Key words: distance learning; expert review; information technology; military education.

\section{References}

1. Jacob W. (2015), Interdisciplinary trends in higher education, Palgrave Communications, Vol. 1, URL:https://www.nature.com/articles/palcomms20151. 2. Concept of creating a distance learning system in the Armed Forces of Ukraine, Access mode: www.mil.gov.ua/science_and_defense 3. Walcutt, J.J. \& Schatz, S. (Eds.) (2019). Modernizing Learning: Building the Future Learning Ecosystem. Washington, DC: Government Publishing Office. License: Creative Commons Attribution CC BY 4.0 IGO 4. Voloshinov S. (2018), Modern trends for higher education in Ukraine/Engineering and Educational Technologies, 6 (4), pp. 38-46. DOI https://doi.org/10.30929/2307-9770.2018.06.04.04

5. Doctrine of Information Security of Ukraine, approved by the Decree of the President of Ukraine № 514/2009 08.07.2009 Access mode: http://www.president.gov.ua 6. M. Moore, (Ed.). Handbook of distance education. Edition 3, Routledge, 2013. 7. Hnidenko M.P., (2009), A new approach to the pedagogical process in the context of informatization, Bulletin of the State University of Information and Communication Technologies, Kyiv, pp 6168. 8. Opar N. (2015), Features of legal and regulatory quality assurance of higher education in Ukraine in the context of European integration. The theory and practice of public administration and local self-government. Electronic scientific professional publication №1. 9. Salkutsan S.M. (2017), Organization and use of distance learning technologies in the Armed Forces of Ukraine, Training manual 124 p. 10. Salkutsan S.M. (2019), Status of the distance learning system of the Armed Forces of Ukraine and views on its further development, Proceedings of the Second International Scientific and Practical Conference "Problems of implementation of distance learning in the educational process of higher military educational Institutions and possible ways to solve it", Kyiv, pp. 170173. 11. Salkutsan S.M. (2019), Substantiation of Recommendations for Improving the Distance Learning System of the Armed Forces of Ukraine: R\&D Report, code "Adele", 185 p. 12. Bykov V., Kukharenko V. (2005) Distance Learning Process: Tutorial, 292 p. 13. Lienkov S.V., Hakhovych S.V., Hunchenko Yu.O., Lukin V.Y., Shvorov S.A. (2014), Construction and use of distance learning systems with elements of artificial intelligence: Monograph, 324 p. 14. Koba O., Pustova C. (2011), ObjectOriented Programming: Laboratory Workshop, 76 p. 